\title{
Digestible lysine and organic zinc for male broiler from 1 to 11 days of age: performance and body composition ${ }^{1}$
}

\author{
Messias Alves da Trindade Neto², Lilian Bernadete Namazu², Estela Kobashigawa2,3, Paula \\ Takeara $^{2}$, Daniella Carolina Zanardo Donato ${ }^{2}$, Ricardo de Albuquerque ${ }^{2}$ \\ 1 Financiamento parcial da Fundação de Apoio à Pesquisa Agrícola - FUNDAG. \\ 2 Departamento de Nutrição e Produção Animal da FMVZ-USP, Campus de Pirassununga, Rua Duque de Caxias Norte, 225, 13630-000, \\ Pirassununga, SP, Brasil. \\ ${ }^{3}$ Bolsista CNPq-Brasil.
}

ABSTRACT - This study evaluated levels of digestible lysine and organic zinc for male Ross strain broilers from 1 to 11 days of age. It was used 1,050 chicks distributed in randomized block design, in $5 \times 2$ factorial scheme, with seven repetitions of 15 birds per experimental unit. The dietary concentrations of digestible lysine were $0.90 ; 1.00 ; 1.10 ; 1.20$; and $1.40 \%$ combined with 43 and $253 \mathrm{ppm}$ zinc chelate. The diets contained 2,965 $\pm 18 \mathrm{kcal} / \mathrm{kg}$ of apparent metabolizable energy (AME) and $21.48 \pm 0.18 \%$ of CP. It was determined chemical composition, protein, lipid, mineral and water depositions on carcass and empty body. There was no interaction among the factors digestible lysine and organic zinc. Effect of zinc concentration increase was observed on greatest deposition of body fat, indicating that there is interference in lipid metabolism of the birds in the studied phase. The most pronounced effects resulted from the dietary inclusion of lysine. There was a linear effect on reconstituted body weight as a response to the increase of dietary lysine, which suggests equal or superior requirement to the greatest studied level. However, the deposition of water and protein on the carcass had a quadratic increase, characterizing higher muscle mass accumulation up to the levels 1.25 and 1.27 of this amino acid in the diet. Considering the studied strain, broiler chickens from the first to the 11 th days of age require $1.28 \pm 0.01 \%$ of digestible lysine, according to the deposition of muscle mass.

Key Words: amino acid, nutrient deposition, nutrition, requirement, zinc

\section{Lisina digestível e zinco orgânico para frangos de corte machos de 1 a 11 dias de idade: composição química e taxas de deposição corporal}

\footnotetext{
RESUMO - Neste estudo foram avaliados níveis de lisina digestível e zinco orgânico para frangos de corte machos da linhagem Ross, na fase de 1 a 11 dias de idade. Utilizaram-se 1.050 pintos distribuídos em delineamento de blocos ao acaso, em esquema fatorial $5 \times 2$, com sete repetições de 15 aves por unidade experimental. As concentrações dietéticas de lisina digestível foram 0,$90 ; 1,00 ; 1,10 ; 1,20 ;$ e $1,40 \%$ em combinação com 43 e 253 ppm de zinco quelato. As dietas continham $2965 \pm 18 \mathrm{kcal} / \mathrm{kg}$ de energia metabolizável aparente (EMA) e 21,48 $\pm 0,18 \%$ de PB. Foram determinadas a composição química, deposição proteica, lipídica, mineral e de água na carcaça e no corpo vazio. Não houve interação dos fatores lisina digestível e zinco orgânico. Efeito do aumento da concentração de zinco foi observado na maior deposição corporal de gordura, indicando haver interferência no metabolismo lipídico das aves na fase estudada. Os efeitos mais pronunciados decorreram da inclusão dietética da lisina. Observou-se efeito linear no peso vivo reconstituído, como resposta ao acréscimo de lisina na dieta, o que sugere exigência igual ou superior ao maior nível estudado. Contudo, a deposição de proteína e água na carcaça teve aumento quadrático, caracterizando maior acúmulo de massa muscular até os níveis 1,25 e 1,27 desse aminoácido na dieta. Considerando a linhagem estudada, frangos de corte machos, do primeiro ao $11^{\circ}$ dia de idade, demandam $1.28 \pm 0.01 \%$ de lisina digestível, segundo a deposição de massa muscular.
}

Palavras-chave: aminoácido, deposição de nutrientes, exigência, nutrição, zinco

\section{Introduction}

In the initial phase of growth after hatching, nutrition aims to maximize growth potential of the broiler which is measured subsequently as production of meat at slaughter.
This phase coincides with the greatest nutritional requirement, the reason why it is important to anticipate the age of the chicken at slaughter. During growth, use efficiency of amino acids is associated with increased muscle mass or nitrogen retention. In this phase of nutrition, lysine becomes 
the benchmark for all other amino acids, since it is directed to protein deposition (Baker \& Han, 1994). The correct supply of dietary lysine for broilers promotes significant improvement in feed conversion and increases breast meat yield (Azcona et al., 2006).

Zinc is a trace mineral essential to the metabolism of protein, carbohydrates, fats and is related to the activity of 300 enzymes in the body. It is essential for cell division and DNA synthesis of protein, thus it is associated with tissue growth and is very important for immune system functions, prostaglandin production and bone mineralization (Cheng et al., 1998). The biological essentiality of zinc results from homeostatic mechanisms, which regulate the absorption and cellular uptake, the distribution in intracellular compartments and excretion (Ferreira et al., 2002).

Spears et al. (1992) suggested that the bioavailability of minerals is higher when they are chelated, which may replace the inorganic sources at lower levels, ensuring the maintenance or improving performance. According to Kerr \& Kidd (1996), zinc participates in the organic structure of approximately 160 enzymes (metalloenzymes) in various animal species and as such, benefits the performance of broilers. Hudson et al. (2005) found that broiler diets supplemented with zinc and amino acids promote growth and feed conversion on birds from 1 to 17 days of age, suggesting that lower levels of the mineral favor absorption of nutrients. Thus, the use of chelated minerals reduces environmental pollution (Lee et al., 2001). Aoyagi \& Baker (1993) observed that the biological value of zinc chelate zinc-lysine in poultry is $111 \%$ compared to zinc sulfate (considered standard: 100\%) using as reference the concentration of mineral in bone.

The objective of this study was to evaluate the effects of dietary lysine, with or without organic zinc, on performance, chemical composition and body nutrient deposition in broilers at the end of the period from 1 to 11 days of age.

\section{Material and Methods}

This experiment was conducted in the poultry facilities in the Setor de Avicultura of the Departamento de Nutrição e Produção Animal (VNP-FMVZ), of Universidade de São Paulo, campus of Pirassununga, Brazil. The climate in the region is subtropical, with dry winters and hot and rainy summers.

To evaluate the performance of the birds, 1,050 Ross male chicks at 1 day of age, with average initial weight of $46 \mathrm{~g}$ were used. The birds were placed in a masonry shed divided into 35 boxes of $4.25 \mathrm{~m}^{2}$, divided into 70 plots, equipped with infrared lamps and sawdust litter. From the first day, the chicks received the experimental diets and water ad libitum.

Diets were formulated to contain $0.90,1.00,1.10,1.20$ and $1.40 \%$ of lysine combined with 43 and $253 \mathrm{ppm}$ of zinc chelate. The diets contained 2,965 $\pm 18 \mathrm{kcal} / \mathrm{kg}$ apparent $\mathrm{ME}$, a value which was determined in a digestibility trial (Namazu et al., 2008) and $21.48 \pm 0.18 \% \mathrm{CP}$ (Table 1). The levels of energy, protein and amino acid ratio were based on recommendations of Rostagno et al. (2005).

After analysis of the diets, the amino acid composition was corrected for digestible values (Table 2). Diets were given ad libitum, based on consumption presented in the strain manual (Agroceres-Ross, 2004) for the period from 1 to 11 days. The remains of food were weighed to determine the average feed intake during the period.

The index of $87.72 \%$ was applied for correction of lysine level estimated by the regression equation. This correction factor $(0.8772)$ was obtained based on the weighted mean digestibility coefficients indicated by Rostagno et al. (2005) for lysine, according to the inclusion of corn, soybean and gluten in the experimental diets.

Calculation: $\mathrm{ATL} \div \mathrm{FDL}=$ Factor $1 \Rightarrow 1.39 \div 1.2=1.158$

Factor $1 \times$ LEEq $=$ Factor $2 \Rightarrow 1.158 \times 1.25=1.447$

Factor $2 \times \mathrm{IDI}=\mathrm{LEc} \Rightarrow 1.447 \times 0.8772=1.269$

in which ATL = analyzed total lysine treatment; FDL = digestible lysine formulated from treatment (it was used the closest value to the value estimated by regression equation);

Factor 1 = first factor; LEEq = lysine level estimated by the regression equation (mean value among the variables); Factor 2 = second factor; IDI $=$ index of digestibility of the ingredients (obtained from the average weight); LEc = estimated lysine corrected.

The experimental design was randomized blocks in a $5 \times 2$ factorial scheme, consisting of the main factors lysine and organic zinc. Formation of the blocks was based on the initial weight of the chicks. Ten treatment combinations were applied with seven replications. The experimental unit was a bird, taken with weight closest to the average weight in each plot according to treatment. Weight gain, body composition (dry matter, protein, lipid and water) and nutrient deposition in carcass and empty body were the variables studied.

At the end of the trial (11 days of age) after 12 hours of fasting, a bird from each plot (15 birds) was sampled, totaling seven replicates per combination. This bird was slaughtered to determine the chemical composition in body fractions (blood-offal and carcass) and empty body, as well as the daily deposition rates. Empty body was defined by the differences among fasting weight and the contents of the gastrointestinal tract. 
Table 1 - Chemical and percentage composition of the experimental diets

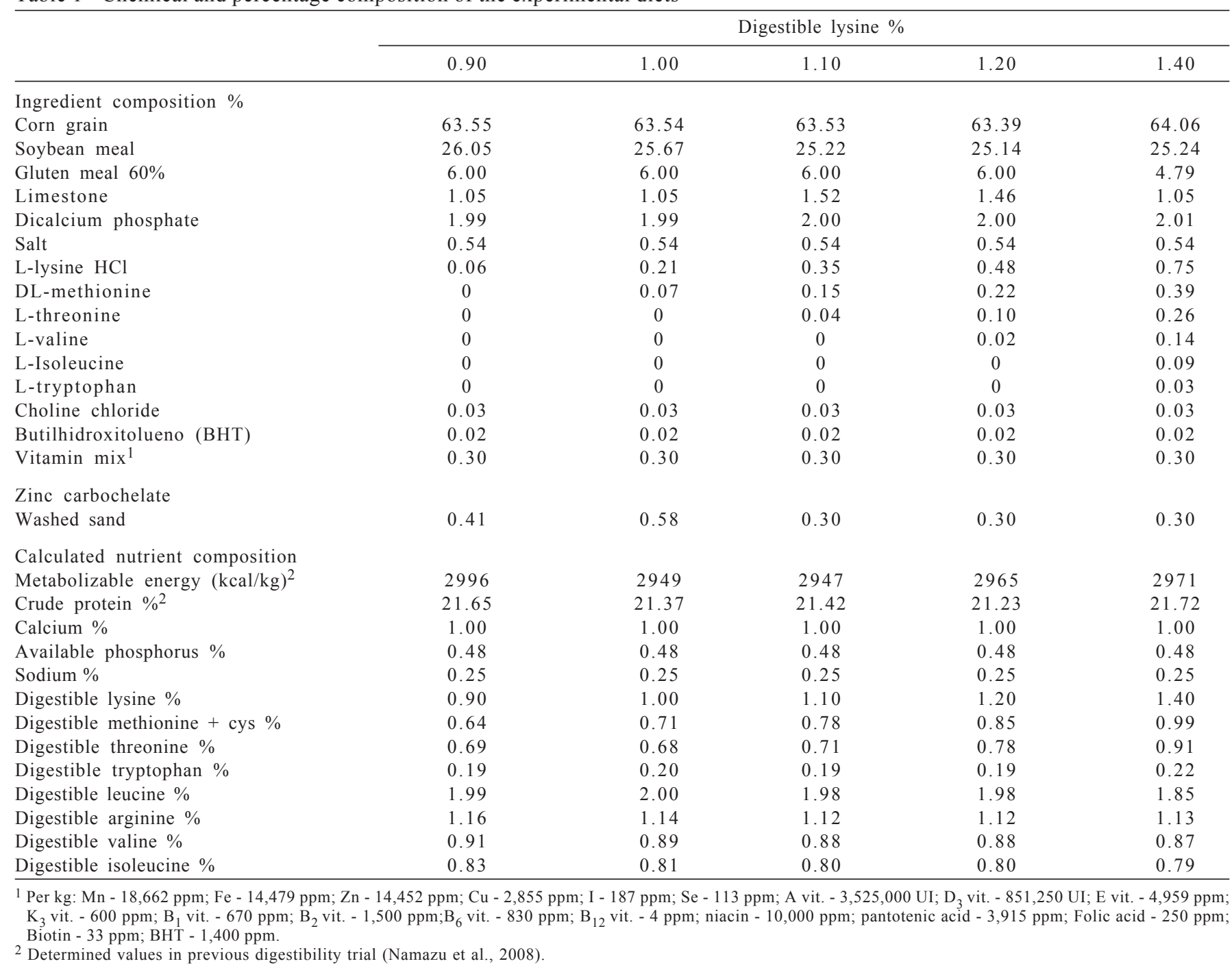

Table 2 - Total amino acid composition of experimental diets ${ }^{1}$

\begin{tabular}{|c|c|c|c|c|c|}
\hline Item \% & \multicolumn{5}{|c|}{ Formulated level of digestible lysine $\%$} \\
\hline Dry matter & 93.39 & 94.90 & 93.04 & 94.84 & 92.77 \\
\hline Lysine & 1.13 & 1.18 & 1.27 & 1.39 & 1.57 \\
\hline Threonine & 0.80 & 0.84 & 0.87 & 0.94 & 1.04 \\
\hline Methionine & 0.38 & 0.42 & 0.47 & 0.52 & 0.67 \\
\hline Cysteine & 0.34 & 0.33 & 0.32 & 0.34 & 0.34 \\
\hline Arginine & 1.39 & 1.32 & 1.33 & 1.43 & 1.53 \\
\hline Aspartic acid & 2.20 & 2.07 & 2.05 & 2.11 & 2.10 \\
\hline Glutamic acid & 4.39 & 4.17 & 4.17 & 4.17 & 4.27 \\
\hline Glicine & 0.95 & 0.90 & 0.90 & 0.92 & 0.88 \\
\hline Histidine & 0.61 & 0.58 & 0.58 & 0.59 & 0.58 \\
\hline Isoleucine & 1.00 & 0.95 & 0.94 & 0.96 & 1.00 \\
\hline Valine & 1.14 & 1.08 & 1.07 & 1.12 & 1.17 \\
\hline
\end{tabular}

\footnotetext{
${ }^{1}$ Analyses conducted by Ajinomoto Biolatin-Brazil.
}

${ }^{2}$ Estimated value based on laboratory analysis and the weighted average relation of $87.72 \%$ digestibility was used as relation to total lysine from the main ingredients. 
The slaughter was carried out by bleeding and the blood was collected in plastic bags and weighed later. The viscera were removed, cleaned, weighed and joined with blood. Then the material was placed below $-10^{\circ} \mathrm{C}$ until processing. The carcasses were cleaned with wet cotton to prevent remnants of blood. After cleaning, they were packed and frozen until processing and preparation of samples, performed at the Laboratory of Meat, Animal Science Institute of Nova Odessa, Sao Paulo.

After being frozen, blood and viscera and carcass of the birds sampled were reduced to a paste by being crushed in meat grinder. Samples of blood and viscera and carcass were removed (approximately $100 \mathrm{~g}$ ) and stored in Petri dishes for freeze-drying in a vacuum system at $5 \mathrm{mmHg}$ of maximum pressure at the initial temperature of $-52^{\circ} \mathrm{C}$, and dried by sublimation. The lyophilized samples were ground in a blender for further chemical analysis.

The dry matter considered was lyophilized dry, but corrected by dry matter at $105^{\circ} \mathrm{C}$, to avoid errors due to absorption of water during the processing of samples. The dry matter, crude protein, ether extract and ash were determined according to AOAC (1984). The determination of crude protein was based on the analysis of nitrogen in Macro Kjehdal with sample previously defatted by using a Soxhlet extractor. The mineral matter was determined by burning the samples in oven at $500^{\circ} \mathrm{C}$ for 16 hours.

For chemical composition, the following contents were considered: water, protein, lipid and ash, expressed in grams or percentage of viscera and blood, carcass and empty body. The difference between body weight after fasting for the sum of weight fractions of the body was considered as water lost by evaporation or in packaging pre-and post-processing. The data were presented as natural matter and dry lyophilized. Deposition rates of water, protein, lipid and mineral in the carcass and empty body were determined from the body composition at the end of the experiment.

Statistical analysis of the variables was performed by using the GLM procedure of the computer program Statistical Analysis System (2004) and regression to levels of lysine. The comparison between averages levels of zinc was given by $F$ test. The mathematical model used was: $\mathrm{Yijk}=\mu+\mathrm{Ai}+\mathrm{Bj}+\mathrm{ABij}+\mathrm{eijk}$,

where Yijk = dependent variables studied in performance analysis; $\mu=$ overall mean of the variable; $\mathrm{Ai}=$ effect of lysine at level $\mathrm{i}$, where $\mathrm{i}=0.90,1.00,1.10,1.20,1.40 \% ; \mathrm{Bj}=$ effect of organic zinc, where $\mathrm{j}=(43$ and $253 \mathrm{ppm}) ; \mathrm{ABij}=$ interaction effect of organic zinc and lysine; eijk = random error associated with each observation.

\section{Results and Discussion}

During the experiment, the maximal and minimal temperature was $25.4^{\circ} \mathrm{C}$ and $18.5^{\circ} \mathrm{C}$ respectively, relative humidity ranged from $86.21 \%$ to $63.35 \%$ and the average rainfall was $124.6 \mathrm{~mm}$. The average temperature in the experimental barn was $27^{\circ} \mathrm{C}$. The rainfall and relative humidity remained in the patterns estimated for the region.

There was no interaction between lysine and zinc levels for the organic chemical composition of blood and viscera, carcass and empty body or for the deposition rates of body protein, fat, water and mineral (Tables 3 and 4 ). Considering the effects of each factor studied, the most pronounced results were due to variation of dietary lysine. The variation in the level of lysine in the diet did not promote changes in the chemical composition of viscera and blood, confirming Friesen et al. (1996) and Lawrence \& Fowler (1997), who observed that lysine is not directed at these fractions.

There was a linear increase $(\mathrm{P}<0.01)$ on fasting body weight, which increased according to the equation $\mathrm{Y}=162.26+109.4305068 \mathrm{X}, \mathrm{R}^{2}=0.72$. Similar responses were observed on measurements taken from empty body with a linear increase $(\mathrm{P}<0.01)$ on weight gain and body weight reconstituted $\left(\mathrm{Y}=102.91+130.427701 \mathrm{X}, \mathrm{R}^{2}=0.81\right)$ in extent that increased the dietary lysine. This variation suggests greater efficiency in the use of amino acids by increasing dietary lysine, as well as its priority for growth of the bird.

Considering the limitation of the responses and the importance of zinc in the multi-enzymatic processes, the highest percentage and fat deposition in empty body of chickens suggest that the mineral has interference on lipid metabolism, as observed in birds fed higher dietary concentration of zinc. In a previous study, Namazu et al. (2008) noted that at higher dietary concentration, the organic zinc provided better response to the use of energy intake when evaluating diets with zinc concentrations similar to this study for broilers (same strain and sex) in the first week of life.

The addition of lysine in the diet coincided with the quadratic variation in protein deposition in the carcass (Table 5). The level estimated as optimal digestible amino acid was $1.25 \%$ (Figure 1). The deposition of water had similar variation in the carcass, which was expected considering the ratio of protein and water in the muscle fraction. In this case, the indicated level of digestible lysine was $1.27 \%$. These variables are related to the gain of muscle mass (protein accretion), especially in periods of higher growth. Based on total lysine and analyzed in the application of the factor of digestibility ( 0.8772 ), these values would be estimated at 1.27 and $1.29 \%$ lysine, respectively. 
Table 3 - Chemical composition from body fractions and empty body of broilers at 11 days of age ${ }^{1}$

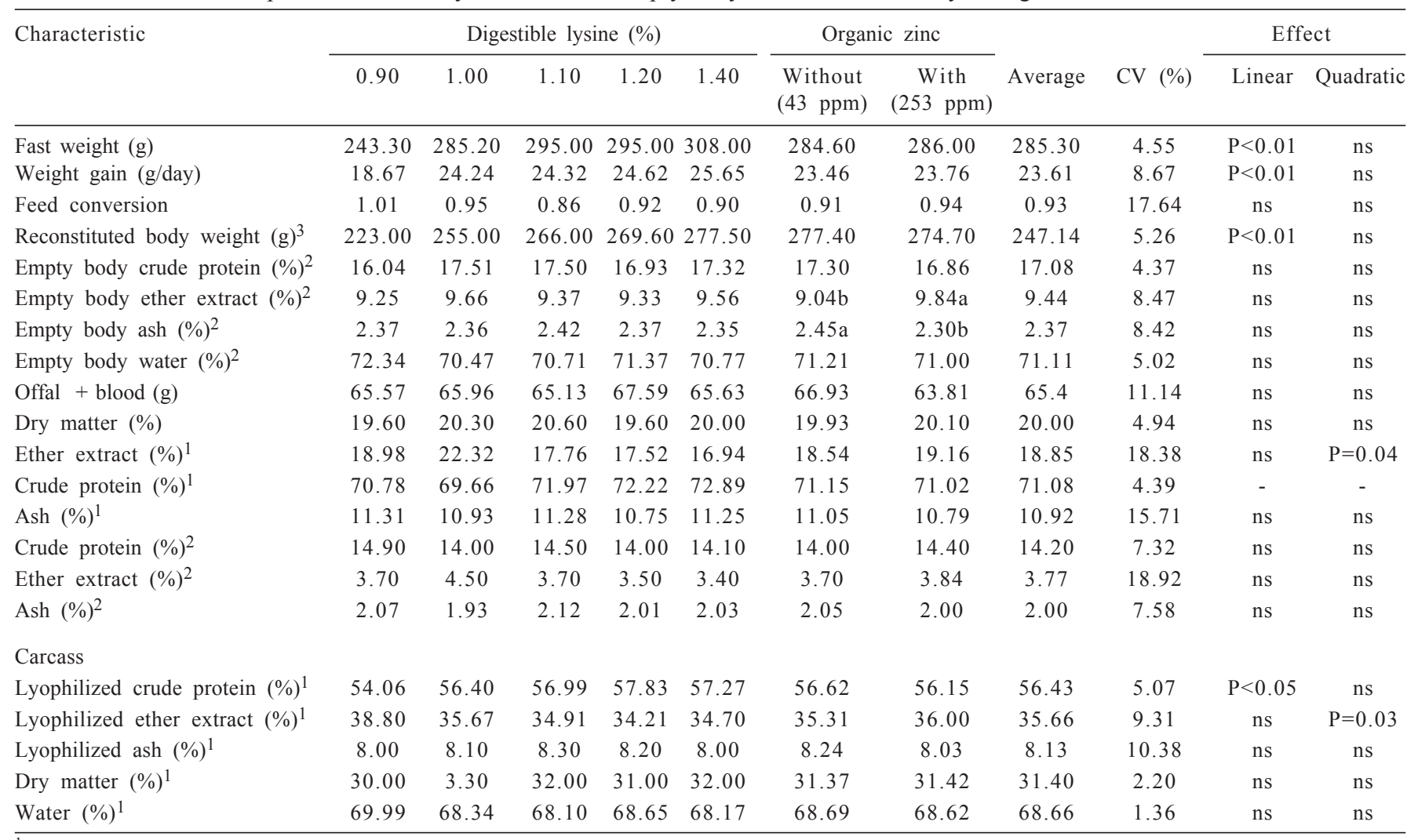

${ }_{1}^{1}$ Data from lyophilized matter basis.

2 Data from natural matter basis.

${ }^{3}$ Reconstituted body weight $=$ sum of body fractions: blood, offal and carcass

Average followed by different letters in same line differ by $\mathrm{F}$ test $(\mathrm{P}<0.05)$. $\mathrm{CV}=$ coefficient of variation.

Table 4 - Chemical composition and deposition on carcass and empty body of broilers sampled at 11 days of age

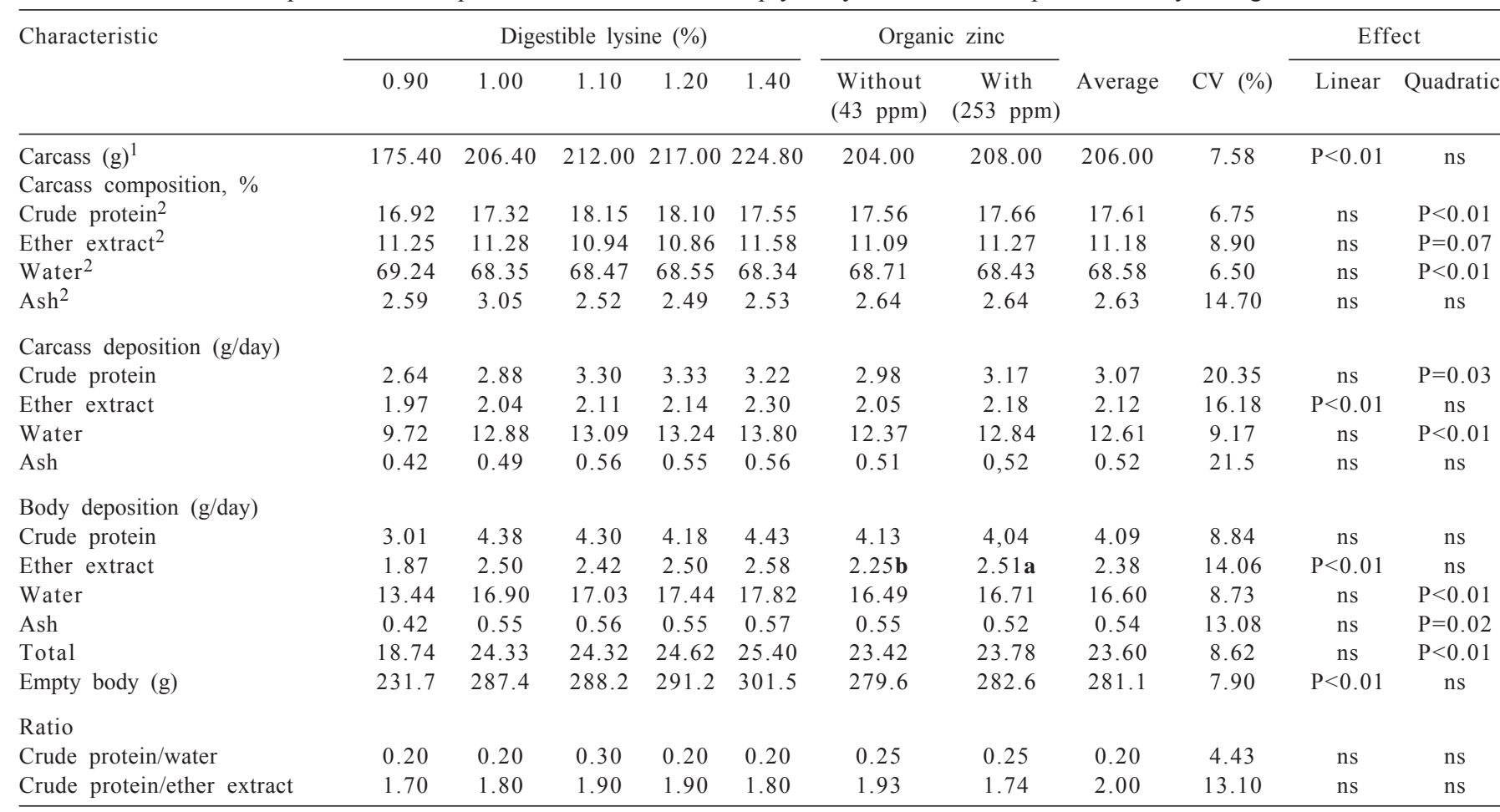

${ }_{1}^{1}$ Carcass with feet, hat and feathers.

2 Percentage on natural matter basis.

Average followed by different letters in same line differ by $\mathrm{F}$ test $(\mathrm{P}<0.05)$. 
Table 5 - Equations for body composition and nutrient deposition, considering the percentage of lysine in the diet for broiler chickens during 1-11 days of age

\begin{tabular}{lll}
\hline Characteristic & Equation of regression & $\mathrm{R}^{2}$ \\
\hline Carcass weight $(\mathrm{g})$ & $\mathrm{Y}=-377.65+932.6699 \mathrm{X}-359.8389 \mathrm{X}^{2}$ & 0.90 \\
Carcass composition & $\mathrm{Y}=2.30+89.2769 \mathrm{X}-35.7557 \mathrm{X}^{2}$ & 0.96 \\
Crude protein $(\%)^{1}$ & $\mathrm{Y}=2.24+33.9141 \mathrm{X}-14.1189 \mathrm{X}^{2}$ & 0.92 \\
Crude protein $(\%)^{2}$ & & \\
Carcass deposition & $\mathrm{Y}=-6.13+15.1606 \mathrm{X}-6.0525 \mathrm{X}^{2}$ & 0.95 \\
Protein (g/day) & $\mathrm{Y}=-28.77+73.7033 \mathrm{X}-28.9841 \mathrm{X}^{2}$ & 0.85 \\
Water (g/day) & & \\
Empty body deposition & $\mathrm{Y}=-28.77+73.7033 \mathrm{X}-28.9841 \mathrm{X}^{2}$ & 0.85 \\
Water (g) & $\mathrm{Y}=-1.23+2.9190 \mathrm{X}-1.1687 \mathrm{X}^{2}$ & 0.84 \\
Ash $(\mathrm{g})$ & $\mathrm{Y}=44.29+110.5738 \mathrm{X}-43.6298 \mathrm{X}^{2}$ & 0.79 \\
Total $(\mathrm{g})$ &
\end{tabular}

${ }^{1}$ Percentage of lyophilized matter.

2 Percentage of natural matter.

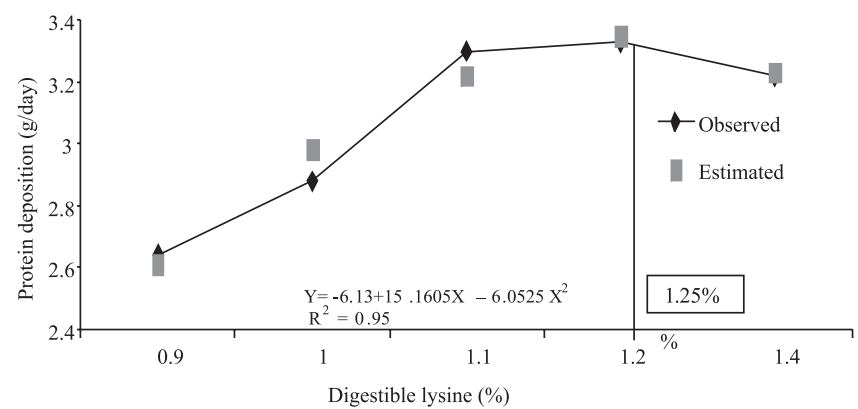

Figure 1 - Deposition of protein on the carcass of broiler chickens fed diets with different levels of lysine.

As described by Leclercq (1998), several authors have shown that supplementation of lysine for maximum growth rate resulted in significant and specific effect on body composition as for example, breast yield, or the modification of fat deposition (Moran Jr. \& Bilgili, 1990; Holsheimer \& Veerkamp, 1992; Mendes et al., 1997; Pavan et al., 2003).

The highest level found for the deposition of protein in the carcass was $1.25 \%$ or $1.27 \%$ digestible lysine, according to the digestibility index (Figure 1). This level is above the estimated weight gain $(1.19 \%)$ when evaluated in vivo performance of the whole lot of birds. This higher value suggests greater need of the amino acid in protein accretion in the carcass. This confirms, therefore, the hypothesis that lysine is targeted for protein synthesis, as suggested by Trindade Neto et al. (2001), and this demand would be higher than those measured in vivo performance.

Carcass fat (Figure 2) has quadratic variation $(\mathrm{P}=0.07)$ in response to increasing dietary lysine and the amino acid level was estimated to 1.13 or $1.148 \%$ by applying the index of digestibility. This variable, however, describes less accurately the response of the effect of nutrition compared to the amino acid composition and protein, or the

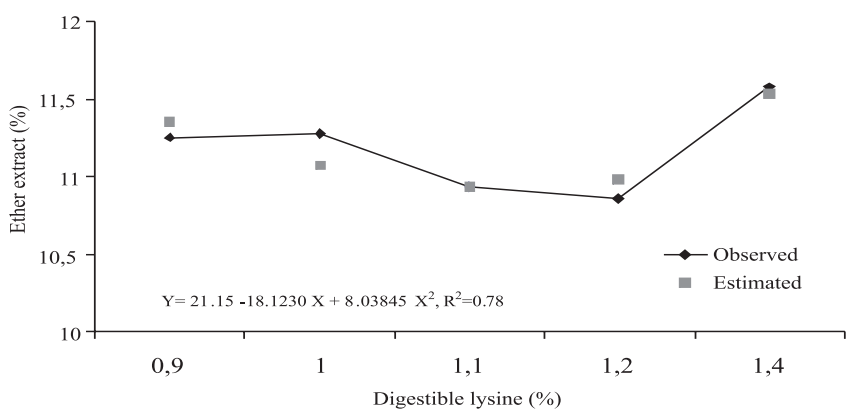

Figure 2 - Ether extract (\% fresh matter) in carcass of broilers fed diets with different levels of lysine.

accumulation of muscle mass in the carcass, especially in relation to lysine.

In the empty body, it was estimated the optimum levels of $1.27,1.25$ and $1.25 \%$ of lysine for water deposition, ash deposition, ash deposition and total deposition in empty body, respectively. In an experiment conducted by Toledo et al. (2007) with birds at the same age, there were no statistical differences among these variables. Information on rates between water and protein, ash and protein in body composition are not well understood, requiring further studies (Eits et al., 2002).

From the present study, the average values for the four highest levels of dietary lysine during the period of 11 days showed average weight gain of $271.8 \pm 6.1 \mathrm{~g}$, feed conversion of $0.91 \pm 0.03$ and consumption of $247.3 \mathrm{~g}$ of feed. For the estimated level of lysine, these values correspond to the following demands averages: $1.15 \mathrm{~g}$ of digestible amino acid per $100 \mathrm{~g}$ of weight gain or $11.55 \mathrm{~g} / \mathrm{kg}$ of weight gain, intake of $0.285 \mathrm{~g} /$ day, $3.14 \mathrm{~g}$ in the period or the amount of $12.7 \mathrm{~g} / \mathrm{kg}$ diet. The converted values of this study were below those proposed by Rostagno et al. (2005) for male broilers from middle to superior performance in the first 7 days of age. 
According to guidelines of the technical manual of the company for genetic strain, the recommended level of lysine is $1.10 \%$ from birth to 10 days of age. This level, however, would be below the level recommended in a previous study (Namazu et al., 2008) when it was suggested $1.19 \%$ of digestible amino acid, based on the variables of in vivo performance. Likewise, the level found by Namazu et al. (2008) is below those observed in this study, taking as basis the variables of body composition. In this case, the optimal level of digestible lysine for male broiler from 1 to 11 days of age is higher than determined on in vivo evaluations.

\section{Conclusions}

Considering the strain, broiler chickens from 1 to 11 days of age require $1.28 \pm 0.01 \%$ of lysine according to the deposition of muscle mass.

\section{References}

ASSOCIATION OF OFFICIAL ANALYTICAL CHEMISTS - AOAC. Official methods of analysis. 14.ed. Arlington: 1984. 972p.

AGROCERES [2004] Manual de manejo de frangos AGROSS. Disponível em: <http://www.agroceresross.com.br/servlet/navSrvt? cmd=listPublicacaoFrango\&id=47>. Acesso em: 14/01/2006.

AOYAGI, S.; BAKER, D.H. Nutritional evaluation of a cooperlysine and zinc-lysine complexes for chicks. Poultry Science, v.72, n.1, p.16-171, 1993

AZCONA, J.; SCHANG, M.; CORTAMIRA, O. [2003]. Nível de lisina nas rações de frangos de corte: Experimento $1-22$ a 42 dias de idade, Experimento $2-36$ a 49 dias de idade. Disponível em: $<$ http://www.lisina.com.br $>$ Acesso em: 21/3/2006.

BAKER, D.H.; HAN, Y. Ideal amino acid profile for chicks during the first three weeks posthatching. Poultry Science, v.73, p.1441-1447, 1994

CHENG, J.; KORNEGAY, E.T.; SCHELL, T. Influence of dietary lysine on the utilization of zinc from zinc sulphate and zinclysine complex by young pigs. Journal of Animal Science, v.76, p.1064-1074, 1998.

EITS, R.M.; KWAKKEL, R.P.; VERSTEGEN, W.A. Nutrition affects fat free body composition in broiler chickens. Journal of Nutritional, v.132, p.2222-2228, 2002.

FERREIRA, W.M.; CAVALCANTE, S.G.; NARANJO, A.P. et al. Biodisponibilidade de diferentes fontes de zinco para coelhos. Arquivo Brasileiro Medicina Veterinária e Zootecnia, v.54, n.6, 2002 (doi: 10.1590/S0102-09352002000600013).

FRIESEN, K.G.; NELSEN, J.L.; GOOGBAND, R.D. The use of compositional growth curves for assessing the response to dietary lysine by high-lean growth gilts. Animal Science, v.62, p.159-169, 1996.
HOLSHEIMER, J.P.; VEERKAMP, C.H. Effect of dietary energy and lysine content on performance and yields of two strains of males broiler chicks. Poultry Science, v.71, p.872-879, 1992.

HUDSON, B.P.; DOZIER III, W.A.; WILSON, J.L. Broiler live performance response to dietary zinc source and the influence of zinc supplementation in broiler breeder diets. Animal Feed Science and Technology, v.118, n.3-4, p.329-335, 2005

KIDD, M.T.; KERR, B.J. Threonine in the poultry nutrition. In MEETING ARKANSAS NUTRITION CONFERENCE, 1996 , Arkansas. Proceedings... Arkansas, 1996. p.203-228.

LAWRENCE, T.L.J.; FOWLER, V.R. Growth of farm animals. Wallingford: Cab International, 1997. 330p.

LECLERCQ, B. Specific effects of lysine on broiler production comparison with threonine and valine. Poultry Science, v.77, p.118-123, 1998 .

LEE, S.H.; CHOI, S.C; CHAE, B.J. et al. Evaluation of metalamino chelates and complexes at various levels of copper and zinc in weanling pigs and broiler chicks. Asian-Aus. Journal of Animal Science, v.14, p.1734-1740, 2001.

MENDES, A.A.; WATKINS, S.E.; ENGLAND, J.A. et al. Influence of dietary lysine levels and arginine:lysine ratios on performance of broilers exposed to heat or cold stress during the period of three to six weeks of age. Poultry Science, v.76, n.3, p.472 $481,1997$.

MORAN JÚNIOR, E.T.; BILGILI, S.F. Processing losses, carcass quality and meat yields for broiler chicken, receiving diets marginally deficient to adequate in lysine prior to marketing. Poulry Science, v.69, p.702-10, 1990.

NAMAZU, L.B.; KOBASHIGAWA, E.; ALBUQUERQUE, R. et al. Lisina digestível e Zn quelado para frangos de corte machos: desempenho e retenção de nitrogênio na fase pré-inicial. Revista Brasileira de Zootecnia, v.37, n.9, p.1634-1640, 2008

PAVAN, A.C.; MENDES, A.A.; OLIVEIRA, E. et al. Efeito da linhagem e do nível de lisina da dieta sobre a qualidade da carne do peito de frangos de corte. Revista Brasileira de Zootecnia v.32, n.6, p.1732-1736, 2003

ROSTAGNO, H.S. Diet formulation for broilers base don total versus digestible amino acids. The Journal of Applied Poultry Research, v.4, p.293-299, 1995.

ROSTAGnO, H.S.; ALBINO, L.F.T.; DOnZELE, J.L. Tabelas brasileiras para aves e suínos. Composição de alimentos e exigências nutricionais. Viçosa, MG: Universidade Federal de Viçosa, 2005. (CD-ROM).

SPEARS, J.W.; SCHOENHERR, W.D.; KEGLEY, E.B. et al. Efficacy of iron methionine as a source of iron for nursing pigs. Journal of Animal Science, v.70, p.243, 1992 (suppl. 1).

STATISTICAL ANALYSES SYSTEM - SAS. SAS user's guide: statistics. 12.ed. New York: Scott, M.L. \& Associates, 2004. $1686 \mathrm{p}$.

TOLEDO, A.L.; TAKEARA, P.; KOBASHIGAWA, E. et al. Níveis dietéticos de lisina digestível para frangos de corte machos no período de 1 a 11 dias de idade: desempenho e composição corporal. Revista Brasileira de Zootecnia, v.36, n.4, p.1090-1096, 2007 (supl.)

TRINDADE NETO, M.A.; BARBOSA, H.P.; KRONKA, R.N. et al. Níveis de lisina para suínos na fase inicial-I do crescimento. Composição das frações e do corpo vazio, e taxas de deposição protéica e lipídica. Boletim de Indústria Animal, v.58, n.1, p.47-58, 2001 